\title{
The Economic Consequences of Wage-Price Guidelines
}

\author{
MICHAEL E, TREBING
}

OLUNTARY wage and price guidelines have now been adopted as a major element in the Government's anti-inflation program. The pricing behavior of firms and wage demands of labor are considered by a large portion of the population to be incompatible with the social objective of reducing inflation. Restraint in wage and price movements is believed to be necessary. Monetary and fiscal restraint alone apparently have been judged as either not being able to accomplish this objective or as carrying too high a cost, in terms of lost output and employment. ${ }^{1}$

Although the guideline approach is popular with the public, remarkably little discussion has been directed toward its implications." In particular, the probable efficiency and distributional consequences of the program have received little public attention.

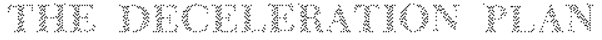

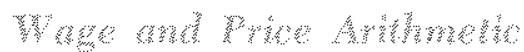

The Administration has set explicit numerical standards for wage and price increases. ${ }^{3}$ The basic guidelines specify that annual increases in wage and fringe benefits be held below 7 percent and that price increases be limited to 0.5 percent less than their annual rate of increase during 1976-77.4 An altemative test for firms is to apply a "profit-test." If a firm cannot meet the price standard, it is requested to limit its pre-tax profit margin on sales to the average of the best two of the past three years. In addition, total profit increases must be below a 6.5 percent ceiling, unless accounted for by volume increases.

The program requires that deceleration of prices be achieved in each market, purportedly with individual

\footnotetext{
1This conclusion is clearly stated in White Paper: The President's Anti-Inflation Program (accompanied the President's announcement of the guideline program on October 24,1978 ) pp. $1-4$.

${ }^{2} \mathrm{~A}$ recent public opinion poll demonstrates the poplarity of the adopted guideline policy. In a November 1978 Harris Poll 63 percent of the respondents supported the program, See Louis Harris, "Americans Support Anti-Inflation Plan;" St. Louis Globe-Democrat, October $20,1978$.

In this article the word "standards" is used interchangeably with guidelines and guideposts. For details of the program see U.S. Council on Wage and Price Stability, Fact Book: Wage and Price Standards issued October 31, 1978.

IIbid. pp. 20-40. The pay standard applies not to individual workers but to average pay increases for "groups" of workers.
}

firms sharing equally in the burden of lowering in. flation. ${ }^{\circ}$ The target for inflation is 6 to 6.5 percent over the first year of the program. In order to reach these objectives, the program's aim is to have prices rise at the same rate as unit labor costs, with average wage increases of 7 percent minus 1.75 percentage points for projected productivity growth yielding an inflation rate of 5.25 percent. The Administration allows an additional 0.5 percent for "legislatively mandated payroll costs" and arrives at a rate of 5.75 percent. ${ }^{6}$ The Administration states: "The wage/price standards are designed to serve as guides for the behavior of decision-making agents who have discretionary power over the prices and the wages that they receive." [emphasis added]

While the guidelines are "voluntary," the Administration has emphasized its intention to compel firms to comply by manipulating both Federal procurement policy and the Government's broad regulatory authority. The program also encourages that the force of public exhortation be directed at those large firms which exhibit "excessive" price increases.

The Administration has requested that Congress pass a "real wage insurance" program. Under this scheme, workers who meet the pay standard will receive a tax rebate if the rate of inflation exceeds 7 percent. The purpose of the rebate is to reduce workers' fear of cooperation by insuring that they will not have their purchasing power reduced if the rate of inffation is not held to less than 7 percent. $^{8}$

\footnotetext{
The price standards are directed at individual firms and apply to an "overall average price" and not to specific products. SSee White Paper, p. 7.

6Fact Book, pp. 15-16. Even with widespread compliance, the Administration concedes that prices will probably rise within the range of 6 to 6.5 percent. This would represent, however, an improvement over the first six months of 1978 when prices rose at a 10 percent annual rate.

ilbid. p. 16. The paragraph contines: "Thus, standards are not directly relevant to pricing behavior in those markets in which prices are determined by the impersonal workings of supply and demand." The program exempts raw materials and anction type markets which include (1) prices of agricultumal and industrial raw materials, (2) interest rates, and (3) prices which historically have moved in tandem with al organized open exchange market.

8 Note that a 7 percent pay increase and a 7 percent intlation rate gives zero increase in real income before taxes - even if productivity rises 1.75 percent, Given the progtession in the income tax structure, real income (after taxes) declines. See Nancy Jianakopolos, "Taying More Taxes and Affording It Less," this Retiew (July 1975), pp. 9-13.
} 


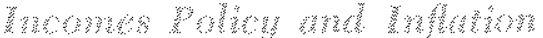

Voluntary wage and price standards can be classified as an "incomes policy". This generic term, loosely defined, inclictes all of those actions taken by a gov. ernment to affect the level of money incomes or prices by actively participating in wage and price decisionmaking.

Alhough more popular in Emopean countries, a wide range of incomes policies have been tried in the United States in recent years." Included have been relatively weak attempts to persuade or "jawbone" specific firms and workers to hold down wage or price increases in the spirit of social responsibility. ${ }^{10}$ Such a program was adopted during the Kennedy Administration and carried over into the early years of the Johnson Administration. At the other extreme, incomes policies have included former President Nixon's rigid program of mandatory criteria for wage and price behavior throughout the entire economy. Guidelines represent an attempt to achieve a compromise between the two extremes. By strengthening the persuasive element used under the jawboning method while attempting to avoid the harsh consequences of strict wage and price controls, guidelines represent a politically tempting route.

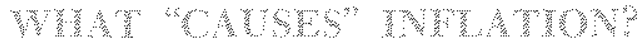

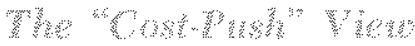

The acceptance of voluntary wage and price standards as an alternative prescription for reducing the general rate of inflation stems from the idea that inflation is generated by "cost-push" factors. This view describes how rising wages, the largest component of business costs, continually force prices upward. The resulting inflation is known to the public as a wage-price spiral. A similar version of this view concludes that inflation is the consequence of increases in the market power of firms and labor over the prices they charge. Accorting to this analysis, prices and wages are "administered" by large firms and trade unions without regard to competitive market forces.

${ }^{9}$ For historical surveys of incomes policy in the United States and abroad see U.S. Congress, Congressional Budget Office Incomes Policies in the United States: Historical Review and Some Issues, May 1977. Lloyd Ulman and Robert Y. Flanagan, Wage Restraint: A Sttdy of Incomes Policies in Western Europe (Berkeley, Califomia: University of California Press, 1971); Walter Galenson, ed., Incomes Policu: What Can We Learn From Europe? (Ithaca, New York: New York State School of Industrial and Labor Relations, Cornell University, 1973); and Craufurd D. Goolwin, ed, Exhottation and Con trols: The Search for Wage-Price Policy, 1945-1971 (Washington, D.C.: The Brookings Institution, 1975).

10"These efforts are sometines referred to as "moral suasion."
The cost-push view has great popular appeal since it depicts the inflation process as a struggle for income shares between capitalists and workers. However, economic theory reveals that many implications of this view of inflation are illogical or, at best, questionable ${ }^{11}$ It is argued that monopoly power exists in the market place and that firms have the ability to push prices above competitive levels and raise the average price level. But this analysis ignores the question of why the monopolies had been charging less than the high monopoly price.

The theory of monopoly pricing predicts that firms which have protection from the entry of competitors into their markets are able to receive prices above those of competitive markets. Once the monopoly price has been achieved, however, further increases are limited to the opportunities provided by the market. If monopoly power is now causing prices to rise, either monopoly power is increasing or monopolists had been behaving irrationally and have just discov. ered theit market advantage. There is little evidence to support either alternative. ${ }^{12}$

Undeniably, many economic groups exhibit enough market power to influence the level of certain prices and wages. These monopoly prices are higher than they would be if the specific market were competitive. But, except for a slight rise due to the resource misallocation, the overall level of prices and wages will remain substantially unchanged. ${ }^{13}$ For example, if wages in a particular industry are pushed up above competitive levels less employment will result. Labor will then be released for use in other sectors where a downward pressure on wages will resalt until a new equilibrium is reached. More importantly, however, this analysis is unable to explain persistent increases in prices, month after month, year after year.

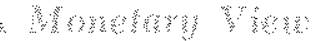

An alternative theory is that inflation is a monetary phenomenon. This view holds that changes in money

"See George J. Stigler, The Organization of Indtustry (Homewood, Illinois: Richard D. Irwin, Inc. 1968) pp. 244-4.5 and Milton Friedman. "What Price Guideposts?", Guidelines: Informal Controls and the Market Place, ed., George P. Shultz and Robert Z. Aliber (Chicago: University of Chicago Press, 1966), pp. $17-39$.

14For a survey of the evidence regarding the relationship between market concentration and price charges see Steven Lustgarten, Industrial Concentration and Infation (Washington, D.C.: American Enterprise Institute for Public Policy Research, 1975).

13 One purpose of a union monopoly, for example, might be to gain real wage benefits for its rank and file. To accomplish this objective the union has several alternatives available to it. It may try to reduce the supply of labor through restrictive licensing practices or by not allowing non-unien workers 
growth exert a strong influence on total spending in the economy. When people find that they are holding cash balances which are greater than desired, they spend the excess money on real and firancial assets and bid up their prices.

The monetary view does not deny the existence of a wage-price spiral, but interprets the cost-push analysis as a confusion of the cause and effect relationships of the inflation process. According to the monetary view, the observed patterns of wage and price adjustments are normal responses to excessive money growth. For inflation to persist, the higher prices, no matter where they originate, must be validated by increases in the money supply. With money growth held constant, price increases can be maintained only through reduced production and employment. For such a situation to persist, businesses would have to willingly accept lower profits and labor would voluntarily remain unemployed and refuse to accept employment at lower wages. The empirical evidence does not support such irrational behavior ${ }^{14}$ Only when monetary authorities actively ensure that the spiral is fully augmented through increases in the money supply, will inflation result.

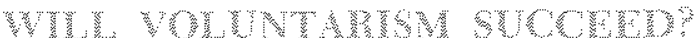

The underlying requirement for a successful guideline policy is that firms and wage-earners restrain themselves from acting economically as individuals. In a market economy the motive of individual selfinterest is crucial. Consumer preferences are revealed through the market by nonrestricted opportunities and/or purchases of goods and services at their market price. These prices reflect not only the costs of production, but also the nature of demand for the good in question. The free movement of prices and the consequent incentives and disincentives that are created assure that resources in the economy will move toward satisfying these individual demands.

An appeal for individual restraint conflicts with a very basic economic observation about human be. havior - consumers naturally strive to maximize their individual well-being. Economic self-interest is the major motivating factor behind economic activity. Guidelines, on the other hand, represent rules that substitute "social responsibility" for self-interest. The conflict between the two views is glaring. Economic incentives argue against individual compliance

to obtain jobs. Secondly, the union might seek a higher wage through collective bargaining and thus accept the unemployment forthoming at this higher wage.

${ }^{14}$ See Denis S. Karnosky, "The Effeet of Market Expectations on Employment, Wages and Prices," Working Paper \#17, Federal Reserve Bank of St. Louis. with the social motives and wealth is tansferred to those who stand apart from the program.

The Kennedy Administration guideposts of 1962-67 represent a prime example of these conflicts. This voluntary program established upper wage limits which were equal to overall productivity gains for the economy. ${ }^{15}$ The problem which restlted in the demise of the productivity rule was that the guideline principles did not take into account the fundamental pressure created by accelerated money growth. When the productivity guidelines were initially adopted, the trend of productivity growth was substantially above the rise in consumer prices. Wages based on the productivity rule thus provided for growth in real wages (money wages adjusted for price changes). As money growth accelerated and inflationary pressures intensified in 1965 and 1966, the wage standard became viewed as unfair. Labor, discovering that the purchasing power of their wages was falling, found the argument for holding down wages unacceptable. As key settlements began to exceed the guideposts, the program was abandoned.

The degree of compliance with price guidelines will be associated with the severity of the penalties against those who choose to ignore them. If the controls are truly voluntary and involve no costs for violation, there is little chance that they will succeed since gains from noncompliance can be realized without costs. If economic sanctions are used against violators, however, each firm will weigh the expected costs and benefits involved. If the expected costs of noncompliance are less than the benefits, the firm will choose to ignore the guidelines. ${ }^{16}$ Avoidance can also take the form of "black-market" transactions above the controlled price or product quality changes.

Though the burden of the program is intended to be equally shared, this will not be the case. Government penalties through procurement policy will not affect private decisions in a uniform fashion. Some firms are dependent upon either government purchases of their output or are directly infuenced by government policies. Other firms, however, may be outside the range of government sanction. Holding down the price of particular goods by penalties benefits the purchasers of these goods and the sellers of unaffected competitive goods. The losers are the sellers of the controlled goods, those prospective buyers of the controlled goods who can no longer

\footnotetext{
15The Council of Economic Advisers, Economic Report of the President (Washington, D.C.: United States Goverment Printing Office, 1962), pp. 185-90.

10"The same type of "cost-beneft analysis" will occur when labor contemplates compliance with wage guidelines and the rebate scheme which supplement them.
} 


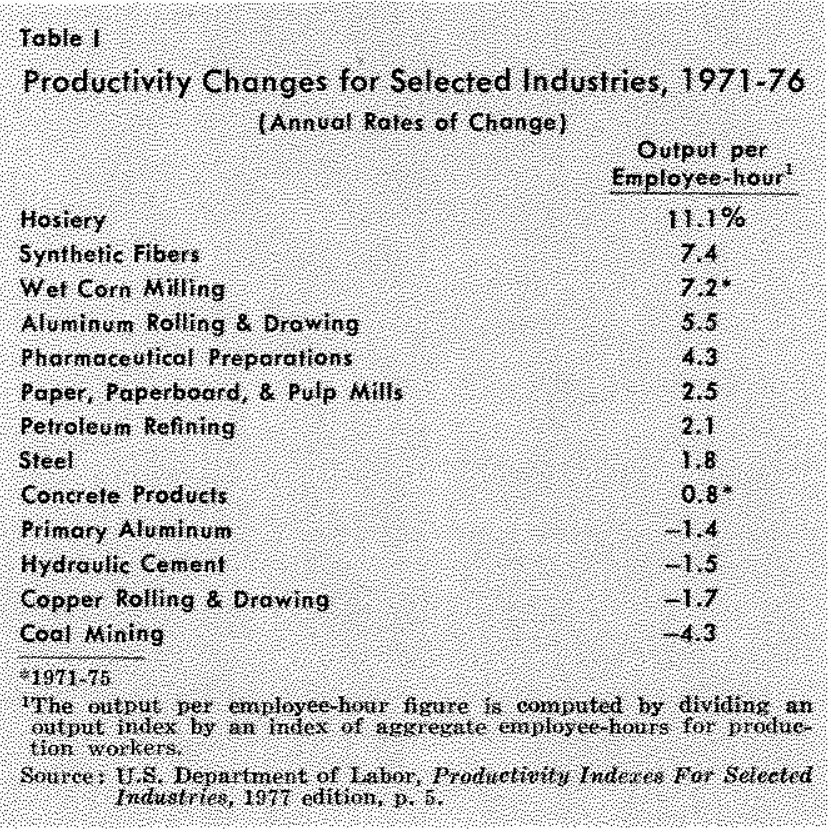

obtain them, and the purchasers of the competitive goods. The losses exceed the gains because of the misallocation of resources.

The proposed "real wage insurance" plan which would supplement the guidelines, if enacted, serves to shift the burden of compliance among economic groups. If certain workers are guaranteed a constant real wage, the forthcoming rebates could reduce real incomes to the rest of the nation provided there is an increase in the federal deficit. To the extent that these larger deficits are "monetized", inflationary pressures will be supplemented, thereby reducing the wealth of all holders of money and monetary instruments. ${ }^{17}$

The real-wage insurance program is said to be capable of breaking inflationary psychology and be able to bring about more rapidly the achievement of price stability. Lower expectations of inflation in the future, according to this view, would translate into lower demands for wage increases and eventually lower prices. This viewpoint, however, confuses how inflation expectations develop. Expectations per se do not cause inflation. Curbing expectations will require controlling of the underlying force which causes them to prevail. If price controls only delay the upward thrust of prices caused by expansive money growth, expectations of future inflation will not be reduced.

If inflation expectations are not reduced by slower monetary growth, the longer-run objective of reaching price stability will be abandoned. For example, since

\footnotetext{
17For an analysis of the administrative problem with the "xealwage insurance" program, see Gardner Ackley, "Oktn's New Tax-Based Incomes Policy Proposal," Economic Outlook USA (Winter 1978), pp. 8-9.
}

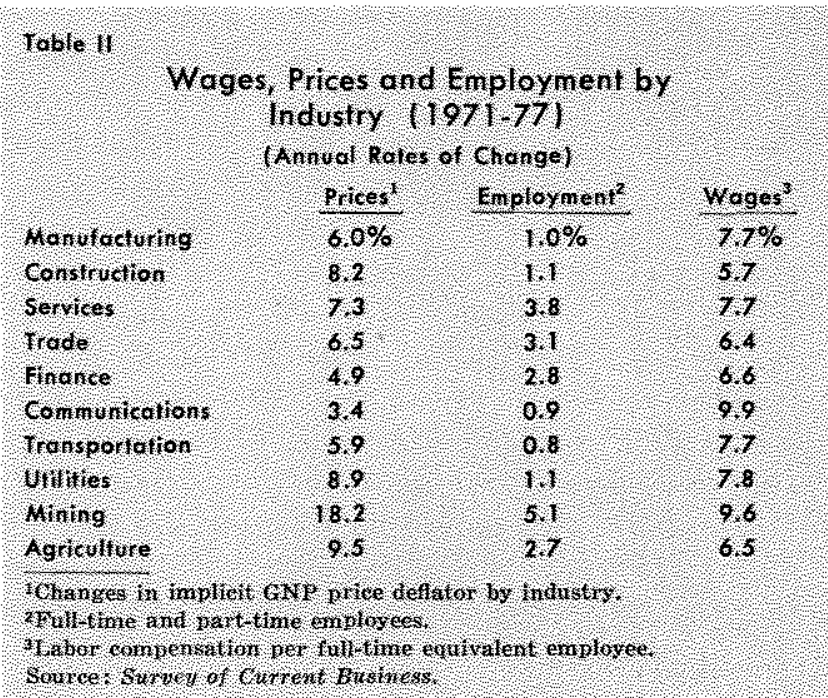

market pressures will eventually push prices upward, reaching the objectives of wage stabilization in the future will be made more difficult. Following a period of controls, a stable wage structure is far more likely to allow a resumption of moderate rates of wage increase than a structure in which distortions, perpetuated by public policies, require rapid readjustment at the bargaining table. Experience with this type of "wage-price explosion" is well documented from European experience with control programs. ${ }^{18}$

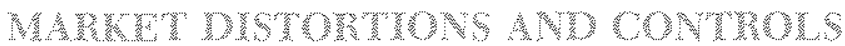

Most economists agree that, for the sake of efficiency, relative wages and prices should remain flexible. Relations among the wages of workers of differ ent skills and of workers in different localities, industries or even firms should be allowed to vary according to changes in demand and supply. For example, firms which are growing have an incentive to hire scarce resources (labor and capital) away from other firms. Consequently, if upper limits are imposed upon the payments that can be offered to attract scarce inputs, the firms will not be able to meet the demand for their output. Relative prices, therefore, should be allowed to move in order to allocate resources into their most productive uses.

The dynamic character of the U.S. economy is evident from Tables I and II. The tables display that changes in employment and prices have varied across industries. Some industries have experienced rapid productivity growth; others have not. Employment growth has varied from industry to industry and generally reflects underlying demand conditions. The application of a single price and wage standard to all situations ignores this ongoing adjustment process

18 Ulman and Flanagan, Wage Restraint, p. 223. 
and confuses movements in relative prices (shifts of resources between economic groups) and the general level of prices. To minimize efficiency losses, it would be necessary to keep a watchful eye on individual wage and price relationships and make exceptions based on individual market situations. A tradeoff is therefore faced by the policymaker. The more stringent the guideline (less exceptions) the greater the efficiency losses. On the other hand, "weak" guidelines are not likely to gain the acceptance of the populace who judge the probable success of the guidelines by the strictness of the program. The program is therefore unlikely to reduce inflation expectations.

Implicit in the decision of who should be covered by guidelines are important judgments regarding the distribution of income among industries and between the factors of production. In other words, control programs politicize questions of income distribution. In a market economy, relative prices are signals that allocate society's resources into their most productive uses. Reflecting changing market conditions, these relative prices are always in motion and are independent of political criteria for distributing income between economic groups. Any guideline based on a simple percentage price increase for all individual firms, however, is implicitly centered on an acceptance of wage and price relationships (at the time of policy implementation) as stable ones and assumes that the relationships will remain fixed throughout the period of the guidelines.

Direct government controls, therefore, offer little inducement for the efficient development and use of resources, and contain no automatic mechanism for resource adjustments and the alleviation of shortages or excesses in production. Rather than being an aid to growth and vitality, they lead to retardation of economic resiliency and replace market forces by political ones.

The U.S. experience with control programs demonstrates these market misallocations. Price controls during World War II resulted in the substitution of low-quality goods for higher quality goods and black markets were commonplace as individuals developed lack of respect for the law. In later years, subsidies to producers became an increasing part of the control program as fixed prices were insufficient to provide the necessary incentives for production. Recent voluntary programs were also unable to avoid selective scarcities. For example, the Kennedy guideposts were blamed for shortfalls in supply of aluminum and sulfur and potential users were forced into using costly substitutes. Similarly, under the Nixon Administration controls, shortages developed for zinc, lead, steel, fer-

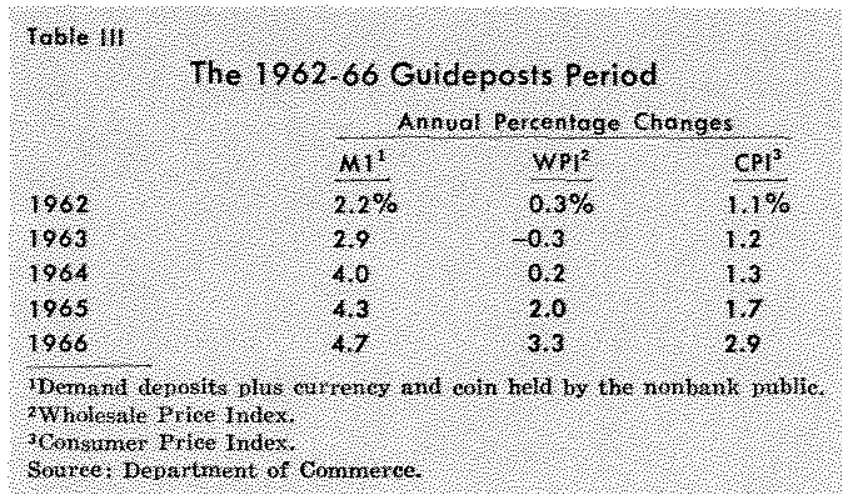

tilizer, petrochemical products and a long list of other products.

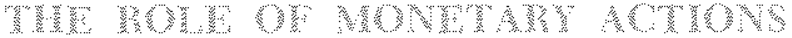

The program is further complicated by the timing of monetary action. In order to validate decelerating inflationary pressures, it will be necessary to supplement the program by tighter monetary action - reducing growth in the money supply. But a problem exists in the timing of monetary actions and the con* trol policy. Relations observed in the past indicate that previous changes in the money supply have effects on current variables - the pattem of aggregate spending is determined by past monetary actions. ${ }^{19}$ A perfectly timed effort by monetary and price control authorities will be difficult to achieve.

The apparent failure of the Kennedy and Nixon control programs to reduce inflation can be interpreted in a monetary framework. A monetary explanation for the failure of the 1962 guideposts is evident in Table III. When the guidelines were adopted, consumer prices were rising at a moderate 0.7 percent rate. (The average change in the Wholesale Price Index between 1958 and 1964 was near zero.) Throughout the life of the guideposts (1962-66), however, money growth increased steadily each year. The money stock grew 1 percent per year from 1959 to 1961, but increased steadily each year of the program. ${ }^{20}$ Correspondingly, prices and wages moved upward reacting to the more rapid growth of spending. When the program was abandoned in 1966, consumer prices were rising at the rate of 3 percent.

During the Nixon price control period (1971-74), money growth data reveals that the controls camou-

\footnotetext{
19 One study which provides a more detalled statement of the theory and evidence supporting these conclusions is Eeonall C. Andersen and Keith M. Carlson, "A Mometarist Model for Economic Stabilization," this Review (April 1970), pp. 7-25. 20 Empirical support for the money-price relationship for the period 1955 to 1971 is presented by Denis S. Karnosky's, "The Link Between Money and Prices - 1971-76," this Revtew (June 1976), pp. 17-23.
} 
flage a period of overly expansive monetary policy during the 1970's. Although non-monetary factors (the oil embargo and the shock of controls) temporarily influenced the money-price relationship, the growth of the price level by 1975 paralleled that rate predicted by the trend growth of money,

Movements in the rate of inflation have been closely associated with movements in the trend growth of the money stock. The accompanying chart shows that both U.S. control periods since World War II have been marked by money growth above its long-run trend. Correspondingly, in both cases rates of change in prices eventually moved upward reflecting this long-run trend.

Without curtailing aggregate spending, individual demands will be simply shifted among controlled and uncontrolled goods. ${ }^{22}$ Holding prices below their market clearing levels will increase the quantity demanded of controlled goods. If total spending is not reduced through monetary or fiscal actions, those who are unlucky and do not receive the goods that would have been supplied without controls, will shift their spending to other products which represent, in most cases, close substitutes. The increased demand in un." controlled markets will put upward pressure on these prices.

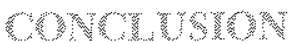

"Voluntary" wage and price guidelines have recently been adopted as an accompanying policy alongside the more traditional economic stabilization tools of monetary and fiscal policy. By establishing rules for pricing behavior, the Administration hopes to dampen a wage-price spiral that appears to be self-sustaining.

21 Ibid.

22"The word "controlled" refers equally to those "voluntary" responses that are reactions to government sanctions.
According to the monetary view of inflation, the logical foundation of the control program confuses the results and causes of inflation. According to this view, inflation results when money growth persistently exceeds growth in the amount of money demanded. The observed wage and price adjusument (the so-called wage-price spiral) are but parts of the general re sponse in the economy to excessive money growth. Inflation expectations, which are generated by exces sive money growth, will be reduced only when the growth rate of money is slowed.

Any short-term benefits received from strict compliance with the guidelines will be costly. The unconstrained market system provides an efficient signaling system for moving resources between alternative uses. Any control framework will probably conflict with these price signals and will cause distortions which reduce the resiliency of the market system to changing market conditions. The emergence of black-markets and disguised price increases through reduced product quality are two examples of devices that have arisen in response to previous programs and may arise in the current program to circumvent the controls.

Past incomes policies in the U.S. have been unable to reduce inflationary pressure because monetary actions remained expansive. If monetary actions remain expansive throughout the current program, accelerated inflation appears inevitable. The fundamental forces of supply and demand cannot be repealed through any type of control program. 